GRASAS Y ACEITES 68 (2)

April-June 2017, e192

ISSN-L: 0017-3495

doi: http://dx.doi.org/10.3989/gya.1058162

\title{
The effects of process technology on the physicochemical properties of peony seed oil
}

\author{
J. Qu ${ }^{\mathrm{a}, \mathrm{A}}$, F. Zhang ${ }^{\mathrm{a}, \mathrm{A}}$, K. Thakur ${ }^{\mathrm{a}}$, J.J. Shi ${ }^{\mathrm{a}}$, J.G. Zhang ${ }^{\mathrm{a}}$, S. Faisal ${ }^{\mathrm{a}}$ and Z.J. Wei ${ }^{\mathrm{a}, \mathrm{b}, \mathbb{}}$ \\ ${ }^{a}$ School of Food Science and Engineering, Hefei University of Technology, Hefei 230009, China \\ ${ }^{\mathrm{b}}$ Agricultural and forestry specialty food processing industry technological innovation strategic alliance of \\ Anhui province, Hefei 230009, China \\ A co-first author \\ ${ }^{\square}$ Corresponding author: zjwei@hfut.edu.cn
}

Submitted: 24 October 2016; Accepted: 06 March 2017

SUMMARY: Peony seed oils (PSOs) were prepared using supercritical $\mathrm{CO}_{2}$ (SC) and compared with soxhlet extraction (SE) and mechanical screw press extraction (SPE) methods. The fatty acid compositions of the oils were determined, and the physicochemical properties of the oils, including free radical-scavenging activity, $\alpha$-amylase and $\alpha$-glucosidase inhibition, thermal and rheological properties were evaluated. The unsaturated fatty acids in the SE oils were higher than SC and SPE oils due to the higher percentage of olefinic, allylic methylene and allylic methine protons in the SE oils. The SPE oils also displayed the highest DPPH and ABTS radical scavenging activity at the tested concentrations. However, the SE oils showed stronger inhibitory effects on $\alpha$-amylase and $\alpha$-glucosidase enzymes under in vitro conditions when compared with the other oil samples. The three oils had similar melting and crystalline point due to similar contents of fatty acids (FAs). The SC oils had a lower $\mathrm{E}_{\mathrm{a}}$ than the others.

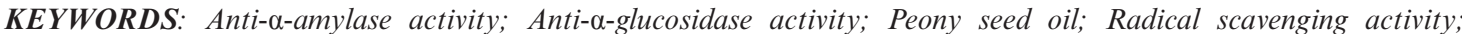
Rheological properties

RESUMEN: Efectos de la tecnología de procesos sobre las propiedades fisicoquímicas del aceite de peonía. Se prepararon aceites de semillas de peonia (PSOs) utilizando $\mathrm{CO}_{2}$ supercrítico (SC) y se compararon con los métodos de extracción en soxhlet (SE) y de extracción mecánica de tornillos (SPE). Se determinaron las composiciones en ácidos grasos y se evaluaron las propiedades fisicoquímicas de los aceites incluyendo la actividad de eliminación de radicales libres, la inhibición de $\alpha$-amilasa y $\alpha$-glucosidasa, las propiedades térmicas y reológicas. Los ácidos grasos insaturados en los aceites SE fueron más altos que los aceites SC y SPE debido al mayor porcentaje de protones olefínicos, metileno alílico y metino alílico en los aceites SE. Los aceites SPE también mostraron una actividad de eliminación de radicales DPPH y ABTS+ más alta a las concentraciones ensayadas. Sin embargo, los aceites SE mostraron efectos inhibidores más fuertes sobre las enzimas $\alpha$-amilasa y $\alpha$-glucosidasa bajo condiciones in vitro cuando se compararon con las otras muestras de aceite. Los aceites tenían puntos de fusión y cristalinos similares debido a un contenido similar de ácidos grasos (FAs). Los aceites $\mathrm{SC}$ tenían un $\mathrm{E}_{\mathrm{a}}$ más bajo que los demás.

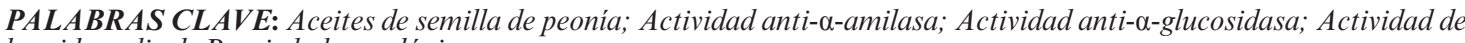
barrido radical; Propiedades reológicas

ORCID ID: Qu J http://orcid.org/0000-0001-6979-6623, Zhang F http://orcid.org/0000-0003-3639-2563, Thakur K http://orcid.org/0000-0001-8441-6537, Shi JJ http://orcid.org/0000-0002-6839-358X, Zhang JG http://orcid.org/00000003-1978-045X, Faisal S http://orcid.org/0000-0001-5018-2701, Wei ZJ http://orcid.org/0000-0003-1729-209X

Citation/Cómo citar este artículo: Qu J, Zhang F, Thakur K, Shi JJ, Zhang JG, Faisal S, Wei ZJ. 2017. The effects of process technology on the physicochemical properties of peony seed oil. Grasas Aceites $\mathbf{6 8}(2)$, e192. http://dx.doi. org/10.3989/gya.1058162

Copyright: (C) 2017 CSIC. This is an open-access article distributed under the terms of the Creative Commons Attribution (CC-by) Spain 3.0 License. 


\section{INTRODUCTION}

Peony (Paeonia suffruticosa Andr.) is a native tree of China, and it is also widely cultivated in many other countries and areas like Japan, Korea, New Zealand, Europe, North America, and other regions (Li et al., 2015). Besides its ornamental value as a flower, the peony is widely used in traditional Chinese medicine and as a functional food due to its various functional constituents (Ning et al., 2015). Peony pods contain two kinds of effective bioactive components namely paeoniflorin and paeonol, which display anti-inflammatory, analgesic and antispasmodic effects on cardiovascular diseases and tumor diseases (Zhu et al., 2013). The dried peony flower has also been exploited to prepare a tea for an antitussive purpose, with strong antioxidant activity due to the presence of anthocyanin. Some studies reported that solvent extracts and essential oils of $P$. suffruticosa flower buds possess potential antimicrobial activities against some of the common food-borne bacterial pathogens (Han and Bhat, 2014; Wang et al., 2004). In the another study, the trans-Resveratrol, 3,5,4'-trihydroxy-trans-stilbene, a stilbenoid compound, known for its therapeutic and pharmacological activities was extracted from peony seeds by the imidazolium-based ionic liquidbased microwave-ultrasonic synergistic simultaneous extraction and hydrolysis methods (Chen et al., 2016). Also, peony seeds are the source of polysaccharides and four types of polysaccharides sequentially extracted from peony seed dregs have displayed strong antioxidant activities in a recent study (Shi et al., 2016).

Tree peony seeds have been recently identified as novel sources of oleic, linoleic and $\alpha$-linolenic acid in China. All these constituents of the edible oil mark the importance of evaluating its nutritional value (Luzzi and James, 2001). Previous reports have suggested that the composition and content of FAs varied dramatically among different cultivars, in which $\alpha$-linolenic acid, linoleic acid, oleic acid, palmitic acid, and stearic acid were the dominant ones ( $\mathrm{Li}$ et al., 2015). Peony seed oil yield increased with seed development and reached its maximum level at the mature stage with values from 29.04 to $34.98 \%$ for different cultivars, and the main components found in mature seeds were linoleic $(30.90 \%), \alpha$-linolenic $(19.71 \%)$, and oleic acids $(42.19 \%)$, which together composed $92.80 \%$ of the total oil (Ning et al., 2015). Seed development led to variation in the FA contents markedly, with low levels of FAs from $10 \mathrm{~d}$ to $30 \mathrm{~d}$ after pollination, which then increased dramatically from $30 \mathrm{~d}$ to $90 \mathrm{~d}$ after pollination, and finally reached their peak at $90 \mathrm{~d}$ after pollination. However, peony seed oil displayed potent inhibition activity against $\mathrm{AChE}$ and $\mathrm{BChE}$ and marked TYRO inhibition, whereas, the oil showed low to moderate antioxidant activity (Sevim et al., 2013). Peony seed oil also possessed potent anti- $\alpha$-glucosidase activity in vitro, decreased blood glucose and the accumulation of hepatic lipids in STZ-induced diabetic mice (Su et al., 2015).

The plant seed oil has been traditionally extracted using the screw press or solvent technique. Although screw press extraction provides the advantages of low operational costs and produces uncontaminated oil, the extraction efficiency is quite low $(<70 \%$ oil extraction). Thus, the supercritical carbon dioxide extraction technology has been studied extensively as an alternative to conventional methods of oil extraction since it is nontoxic, nonflammable and easily separated from the extract (Pang et al., 2015). SC extraction has been widely applied to extract oil from plant seeds, such as canola seed (Pederssetti et al., 2011), kenaf seed (Abd Ghafar et al., 2013), Phaleria macrocarpa seed (Azmir et al., 2014) and okra seed (Dong et al., 2014). In one study, where peony seed oil was mainly extracted using the screw press and solvent methods, it was demonstrated that extraction at atmospheric pressure resulted in the absence of linolenic acid, while extraction under 350 MPa exhibited the highest fatty acid number and fat acidity among all the oils (Wang et al., 2015).

Nowadays, the methods to extract peony seed oil include organic solvent extraction, ultrasonic extraction, squeezing extraction and supercritical $\mathrm{CO}_{2}$ assisted extraction. Sevim et al. (2013) found that the oil extracted from Paeonia L. (peony) using ethanol at room temperature is rich in oleic, linoleic, and linoleic acids. However, to date no studies have been published on the impact of the comparison of different extraction methods on the peony seed oil composition either qualitatively or quantitatively. While composition, acid value, Saponification value, and Iodine value of oil determines its edible properties as food. Similarly, thermal characteristics and liquid viscosity also play an important role in the design of process equipment for the fatty acid industry. The process piping design and pressure drop determination also require viscosity data. Additionally, the viscosity of the individual fatty acid components may estimate the viscosity of mixtures of fatty acids. Thus, it is important to understand the relationship between the physicochemical properties and preparation process. The present study is aimed at supplying the basis for the utilization of peony seed oil as a functional food. The effects of process technology on its nutraceutical properties, antioxidant ability and inhibitory potential on $\alpha$-amylase and $\alpha$-glucosidase enzymes were investigated; and then the thermal characteristics and liquid viscosity of the oils extracted by different methods were evaluated. There have been reports of extraction of peony seed oil in the past years but we have compared the three different extraction methods and this is the first ever study to evaluate the thermal and liquid viscosity properties of peony seed oil. 


\section{MATERIALS AND METHODS}

\subsection{Materials}

Peony seeds were obtained from the Beijing Tong Ren Tang Anhui Chinese Herbal Medicine Co., Ltd. The seeds were dried at $60{ }^{\circ} \mathrm{C}$ to reach a stable moisture content of less than 4\%. Dry seeds were grounded to a fine powder and passed through the 60 mesh sieve. The powder was stored at $4{ }^{\circ} \mathrm{C}$. Carbon dioxide (purity $99.9 \%$ ) was purchased from Henglong Gas Corp (Anhui, China). n-hexane for Gas Chromatography (GC) and Gas Chromatography-Mass Spectrometry (GC-MS) were of HPLC grade. Other solvents and chemicals were of analytical grade.

\subsection{Extraction of peony seed oil}

Supercritical $\mathrm{CO}_{2}$ extraction: The procedures were designed and modified according to the description by Dong et al. (2014). The seed oil was extracted using an SC system (Model HA220-50-06, Jiangsu, China). In brief, $100 \mathrm{~g}$ of the ground peony seeds were added to the extraction vessel and liquid $\mathrm{CO}_{2}$ was transferred to the extraction vessel by a high-pressure pump to the proposed pressure. The parameters of extraction procedure were as follows: optimized condition at $24 \mathrm{MPa}, 21 \mathrm{~L} / \mathrm{h}, 46{ }^{\circ} \mathrm{C}$ and 124 min (Data presented in supplement).

Soxhlet extraction: The peony seed powder $(20 \mathrm{~g})$ was extracted with $\mathrm{n}$-hexane using a soxhlet device at $80^{\circ} \mathrm{C}$ for $8 \mathrm{~h}$. The solvent was removed in a rotary evaporator under vacuum at $40{ }^{\circ} \mathrm{C}$ after extraction (Dong et al., 2014).

Screw press expression: The peony seed powder $(1000 \mathrm{~g})$ was fed from the hopper to the screw press on demand by expeller and the oils were collected at the oil outlet (Dong et al., 2014).

All oil samples were separated by centrifuging at $9000 \mathrm{rpm}$ for $10 \mathrm{~min}$ and kept at $4{ }^{\circ} \mathrm{C}$.

\subsection{Gas chromatography-mass spectrometry (GC-MS)}

The collected oils were converted to fatty acid methyl esters (FAMEs) via esterification reaction at first (Wei et al., 2009). Briefly, the PSOs prepared above were dissolved in a $3.0 \mathrm{~mL}$ methanol solution containing 5\% concentrated sulphuric acid, vortexed for $2 \mathrm{~min}$, and placed in a $90{ }^{\circ} \mathrm{C}$ water bath for $1 \mathrm{~h}$ to induce derivatization. Afterwards, samples were removed and allowed to cool to room temperature. Then, $2.0 \mathrm{~mL}$ of deionized water were added to terminate the derivatization reaction. FAMEs were subsequently extracted with $3 \mathrm{~mL}$ of $\mathrm{n}$-hexane, then the solutions were centrifuged (3000 rpm, $10 \mathrm{~min}$ ), and the supernatants were collected. The concentrated solutions were re-dissolved in an appropriate n-hexane volume and dehydrated using anhydrous sodium sulfate.

A GC-MS analysis was carried out according to the SCION SQ system (BRUKER Ltd. USA). The conditions were as follows: Column: BR-WAX $(60.0 \mathrm{~m} \times 0.25 \mathrm{~mm} \times 0.25 \mu \mathrm{m})$; oven temperature program: The initial column temperature was maintained at $60{ }^{\circ} \mathrm{C}$ for $3 \mathrm{~min}$ before it was increased by $10^{\circ} \mathrm{C} \cdot \mathrm{min}^{-1}$ to $185^{\circ} \mathrm{C}$ and kept for 1 min then raised to $200^{\circ} \mathrm{C}$ for $10 \mathrm{~min}$ with $5^{\circ} \mathrm{C} \cdot \mathrm{min}^{-1}$. The final temperature was $220{ }^{\circ} \mathrm{C}$ increased by $5{ }^{\circ} \mathrm{C} \cdot \mathrm{min}^{-1}$ and maintained for $20 \mathrm{~min}$. The temperatures of the interface and the ion source were $250{ }^{\circ} \mathrm{C}$ and $280^{\circ} \mathrm{C}$ respectively, while the injector temperature was set at $250^{\circ} \mathrm{C}$; injection volume: $1.0 \mu \mathrm{L}$, ionization energy: $70 \mathrm{eV}$; mass range: $35-450$ atomic mass units (amu).

\section{4. ${ }^{1} \mathrm{H}$ NMR analysis}

${ }^{1} \mathrm{H}$ NMR was detected on a VNMRS600 Agilent at $500 \mathrm{MHz}$ at $25^{\circ} \mathrm{C}$. The oil $(0.2 \mathrm{~g})$ extracted by different methods was dissolved in $\mathrm{CDCl}_{3}$ for spectral analysis.

\subsection{Chemical properties of the PSOs}

The chemical properties of PSOs containing the saponification value (AOAC 920.160), acid value (AOAC 969.17), iodine value (AOAC 993.20), peroxide value (AOAC 965.33), were conducted through the official procedure, and each experiment was run in triplicate.

\section{6. $\mathrm{DPPH}$ and $\mathrm{ABTS}^{+}$free radical-scavenging activity}

The stable diphenyl-picryl hydrazinyl radical (DPPH·) scavenging activity was determined by the modified method described by Diaby et al. (2016). Briefly, the oils extracted with different methods were diluted to varying concentrations with ethanol. Then the samples were mixed with $5.0 \mathrm{~mL}$ of a DPPH solution $(0.04 \mathrm{mg} / \mathrm{mL})$. The mixtures were incubated at room temperature for $30 \mathrm{~min}$ in the dark. The remaining DPPH amount was determined at $517 \mathrm{~nm}$. The BHT solution served as a positive control.

The antioxidant activity of seed oils was measured by the $\mathrm{ABTS}^{+}$radical cation $\left(\mathrm{ABTS}^{+}\right.$.) decolorization assay using the method adapted by Azhari et al. (2014). Briefly, A solution containing $\mathrm{ABTS}^{+}$. was prepared by mixing an equal volume of ABTS $(7 \mathrm{mM})$ and potassium persulfate $(2.45 \mathrm{mM})$. Then the mixture kept for $16 \mathrm{~h}$ in the dark at room temperature. The $\mathrm{ABTS}^{+}$.stock solution was diluted with ethanol (ratio 1:50) to obtain an absorbance of $0.70 \pm 0.02$ at $734 \mathrm{~nm}$. Then the different concentrations of samples were added to the tubes and mixed with $3 \mathrm{~mL}$ of $\mathrm{ABTS}^{+}$. dilution. The mixtures were incubated for $10 \mathrm{~min}$ and the absorbance was 
determined at $734 \mathrm{~nm}$. EDTA-2Na was employed as the positive control. Inhibition of the DPPH $\cdot$ or $\mathrm{ABTS}^{+} \cdot$ in percent $(\mathrm{I} \%)$ was calculated using the formula below:

$I \%=\left(A_{\text {blank }}-A_{\text {sample }}\right) / A_{\text {blank }} \times 100 \%$

Where $\mathrm{A}_{\text {blank }}$ represents the absorbance of the reaction without oil samples, and $\mathrm{A}_{\text {sample }}$ is the absorbance of the reaction mixed with the oil samples. The results were expressed as mean $\pm \mathrm{SD}$. via triplicate parallel experiments.

\subsection{Measurement of $\alpha$-amylase and $\alpha$-glucosidase inhibition}

The evaluation of $\alpha$-amylase inhibition followed the methods of Jadhav and Singhal (2013). A $600 \mu \mathrm{L}$ starch solution $(1.5 \% \mathrm{w} / \mathrm{v})$ was diluted with $20 \mathrm{mM}$ phosphate buffer ( $\mathrm{pH} 6.9$ with $6.5 \mathrm{mM}$ $\mathrm{NaCl}$ ) and mixed oils of various concentrations and then incubated at $37^{\circ} \mathrm{C}$ for $10 \mathrm{~min}$. The reaction was initiated by adding $\alpha$-amylase $(2.0 \mathrm{U} / \mathrm{mL})$ solution and holding for $5 \mathrm{~min}$ at $37^{\circ} \mathrm{C}$. Then the mixture was put in a boiling water bath for $5 \mathrm{~min}$ after the addition of $1 \mathrm{~mL} 3,5$-dinitrosalicylic acid solution to stop the reaction and cooled to room temperature. The reaction mixture was diluted by adding $30 \mathrm{~mL}$ distilled water and absorbance at $540 \mathrm{~nm}$ was measured. The deionized water instead of $\alpha$-amylase solution and acarbose were used as blank and positive control, respectively. Each experiment was conducted in triplicate.

The $\alpha$-glucosidase inhibitory activity was assayed according to the chromogenic method described by Zhang et al. (2015) with some modifications. Oils of various concentrations were mixed with $100 \mu \mathrm{L}$ of $\alpha$-glucosidase $(1.0 \mathrm{U} / \mathrm{mL})$ in $0.1 \mathrm{M}$ phosphate buffer $(\mathrm{pH}=6.9)$ solution followed by the addition of $1.0 \mathrm{~mL}$ $0.1 \mathrm{M}$ phosphate buffer $(\mathrm{pH}=6.9)$. The mixtures were kept at $37^{\circ} \mathrm{C}$ for 20 min after mixing with $5.0 \mathrm{mM}$ of $100 \mu \mathrm{L}$ p-nitrophenyl- $\alpha$-D-glucopyranoside $(0.1 \mathrm{M}$ PBS, $\mathrm{pH}=6.9$ ) then pre-incubated for $10 \mathrm{~min}$ at $37^{\circ} \mathrm{C}$. $2.0 \mathrm{~mL}, 0.2 \mathrm{M}$ sodium carbonate was added to the reaction mixtures to stop the reaction before reading the absorbance at $405 \mathrm{~nm}$ in the spectrophotometer. The mixtures without $\alpha$-glucosidase and acarbose were used as blank and positive control, respectively. The results were calculated according to the same formula given for the DPPH radical scavenging test. Each experiment was conducted in triplicate.

\subsection{Thermal analysis of the PSOs}

Differential scanning calorimetry (DSC) curves were obtained by TA Instruments Q200 (TA Instruments, USA) under $\mathrm{N}_{2}$ flow $\left(20 \mathrm{~mL} \cdot \mathrm{min}^{-1}\right)$, at a heating rate of $20^{\circ} \mathrm{C} \cdot \mathrm{min}^{-1}$, in $10 \mu \mathrm{L}$ sealed aluminum capsules. For the study of the thermal property at low temperatures, samples were cooled to $-80{ }^{\circ} \mathrm{C}$ and then heated to $+20^{\circ} \mathrm{C}$ at a rate of $10^{\circ} \mathrm{C} \cdot \mathrm{min}^{-1}$.

\subsection{Rheological properties}

The rheological characteristics of the oils were determined by a rotator rheometer (DHR-3, TA Instruments Ltd., USA). Each sample was place equilibrated to the required temperatures $(10,30$ and $50{ }^{\circ} \mathrm{C}$ ) on the temperature-controlled vessel. Viscosity was tested at various shear rates from 0.1 to $200 \mathrm{~s}^{-1}$. The flow behavior of the oils was equipped with Casson equation as it works well at various shear rates (Sathivel et al., 2003).

$t_{x y}^{0.5}=t_{0}^{0.5}+h_{c}^{0.5}\left(d V_{x} / D_{y}\right)^{0.5}$

Where $\tau_{\mathrm{xy}}$ is shear stress $(\mathrm{Pa}), \tau_{0}$ is yield stress $(\mathrm{Pa})$, $\eta_{\mathrm{c}}$ is higher shear limiting viscosity (Pa.s) and $\mathrm{dV}_{\mathrm{x}} I$ $\mathrm{D}_{\mathrm{y}}$ is shear rate.

The influence of temperature on viscosity for PSOs can be described by the Arrhenius type of equation and formula as:

$\mu=A e^{E_{a} / R T}$

Where $\mu$ is viscosity (Pa.s), A is equation constant, $E_{a}$ is the energy of activation for viscosity, $R$ is the universal gas constant, $\mathrm{T}$ is the absolute temperature.

\section{RESULTS AND DISSCUSSION}

\subsection{The composition of PSOs}

The compositions of the PSOs extracted by SC, SE and SPE were analyzed by gas chromatography-mass spectrometry, and represented as percentage chromatographic area (Table 1). Only slight differences could be observed in the compositions of the oils extracted by the three methods. Seven types kinds fatty acid were detected in the SE oils, two FAs, hexadecenoic and eicosanoic acid were at trace levels and hexadecenoic acid was absent in SC oil. There were five dominant fatty acids, namely, $\alpha$-linolenic, linoleic, oleic, palmitic, and stearic acid in all three oil samples. SE oil contained the highest proportion $(93.63 \%$ ) of UFAs, followed by SC oil $(91.92 \%)$ and SPE oil $(89.59 \%)$, but no difference was observed. Among the three types, $\alpha$-linolenic acid was the dominant compound, which rangedg from $38.63 \%$ to $40.45 \%$ (Table 1 ).

\section{2. ${ }^{1} \mathrm{H}$ NMR analysis}

The results from the ${ }^{1} \mathrm{H}$ NMR analysis revealed that the percentage of olefinic, allylic methylene and allylic methine protons were higher in SE oils than those in the SC and SPE samples (Table 2). Therefore, 
it is clear that the percentage of unsaturation along with conjugated unsaturated fatty acids in SE oils were the highest among the three samples used in the study. The peak at 3.6-3.8 ppm was relatively weak, which implied that the content of methoxy/ fatty acid methyl ester in PSOs was low. The peaks at $1.0-1.8 \mathrm{ppm}$ and $0.5-1.0 \mathrm{ppm}$ were almost the same in all samples (Table 2), which suggested that the process showed almost no effects on the content of $-\mathrm{CH}_{3}$ and $-\mathrm{CH}_{2}$-. Pradhan $\mathrm{RC}$ reported that the percentage of unsaturation of the fatty acids in flaxseed oils from the SC extraction process were higher than those by soxhlet and the screw press extraction processes (Pradhan et al., 2010). The deference may be attributed to different properties in the raw material.

\subsection{Physicochemical properties of the PSOs}

As shown in Table 3, the acid value of the oil by SE reached $2.79 \mathrm{mg}$ of $\mathrm{KOH}$ per $\mathrm{g}$ of oil, which is significantly higher than that of SPE $(1.88 \mathrm{mg}$ of
$\mathrm{KOH}$ per $\mathrm{g}$ of oil) and $\mathrm{SC}(1.65 \mathrm{mg}$ of $\mathrm{KOH}$ per $\mathrm{g}$ of oil) $(\mathrm{P}<0.05)$ (Table 3$)$. This phenomenon also occurred in flaxseed oil by different methods (Pradhan et al., 2010). The peroxide value and saponification value of SE were higher than those obtained by SPE and SC, yet the difference was not significant. The Iodine value of the three samples showed no significant difference (Table 3 ).

\subsection{DPPH and ABTS+ free radical-scavenging activity}

Both the DPPH and $\mathrm{ABTS}^{+}$radical-scavenging activity of all the PSO samples increased in a dose dependent pattern (Figure 1). At the same concentration, the scavenging activities of SPE oils measured by DPPH and $\mathrm{ABTS}^{+}$radical were the highest, followed by SC oils. The DPPH radical-scavenging activity of SPE reached $81.08 \%$ at $10 \mathrm{mg} / \mathrm{mL}$, whereas it rose to $38.30 \%$ and $72.51 \%$ for SE and SC oils; while the activity by BHT (as control) was

TABLE 1. Main fatty acid compositions and content of PSOs

\begin{tabular}{lccc}
\hline & \multicolumn{3}{c}{ Percentage (\%) } \\
\cline { 2 - 4 } Fatty acid & SC oils & SE oils & SPE oils \\
\hline Palmitic acid (16:0) & $6.82 \pm 1.62$ & $5.11 \pm 1.34$ & $0.85 \pm 1.65$ \\
Hexadecenoic acid (16:1) & ND. & $0.13 \pm 0.07$ & $0.06 \pm 0.04$ \\
Stearate acid (18:0) & $1.21 \pm 0.15$ & $1.13 \pm 0.21$ & $1.45 \pm 0.18$ \\
Oleic acid (18:1) & $24.49 \pm 1.13$ & $25.88 \pm 1.34$ & $23.27 \pm 1.86$ \\
Linoleic acid (18:2) & $27.89 \pm 1.53$ & $27.17 \pm 1.56$ & $27.63 \pm 1.48$ \\
$\alpha$-Linolenic acid (18:3) & $39.54 \pm 1.84$ & $40.45 \pm 1.64$ & $38.63 \pm 1.58$ \\
Eicosanoic acid (20:0) & $0.05 \pm 0.04$ & $0.13 \pm 0.67$ & $0.11 \pm 0.08$ \\
UFAs & $91.92 \pm 1.85$ & $93.63 \pm 1.24$ & $89.59 \pm 1.25$ \\
\hline
\end{tabular}

Each value is an average of three determinations, mean \pm SD. UFAs unsaturated fatty acids, ND. not detected.

TABLE 2. ${ }^{1} \mathrm{H}$ NMR profile of fatty oils (percentage of total hydrogen) obtained by different extraction methods

\begin{tabular}{llccc}
\hline Chemical shift $\mathbf{( \$ )}(\mathbf{p p m})$ & Type of hydrogen & SE oils & SC oils & SPE oils \\
\hline $5.2-5.7$ & Olefinic protons & 14.31 & 12.58 & 12.16 \\
$4.1-4.5$ & Allylic methine protons & 5.23 & 4.81 & 4.52 \\
$3.6-3.8$ & Methoxy protons & 0.83 & 1.23 & 0.84 \\
$2.0-3.0$ & Allylic methylene protons & 25.55 & 24.85 & 24.13 \\
$1.0-1.8$ & $-\mathrm{CH}_{2}$ - protons & 46.32 & 47.49 & 48.93 \\
$0.5-1.0$ & $-\mathrm{CH}_{3}$ protons & 7.76 & 9.04 & 9.42 \\
\hline
\end{tabular}

TABLE 3. Chemical properties of PSOs

\begin{tabular}{lccc}
\hline Oil properties & SC oils & SE oils & SPE oils \\
\hline Acid value (mg of KOH per g of oil) & $1.65 \pm 0.17^{\mathrm{a}}$ & $2.79 \pm 0.28^{\mathrm{b}}$ & $1.88 \pm 0.26^{\mathrm{a}}$ \\
Peroxide value (meq of $\mathrm{O}_{2}$ per kg of oil) & $1.46 \pm 0.23^{\mathrm{a}}$ & $1.83 \pm 0.15^{\mathrm{a}}$ & $1.48 \pm 0.19^{\mathrm{a}}$ \\
Saponification value (mg of KOH per g of oil) & $178.32 \pm 10.38^{\mathrm{a}}$ & $193.57 \pm 11.23^{\mathrm{a}}$ & $182.87 \pm 9.85^{\mathrm{a}}$ \\
Iodine value (g of $\mathrm{I}_{2}$ per 100 g of oil) & $164.55 \pm 11.02^{\mathrm{a}}$ & $174.83 \pm 8.41^{\mathrm{a}}$ & $175.45 \pm 9.05^{\mathrm{a}}$ \\
\hline
\end{tabular}

Each value is an average of three determinations, mean \pm SE. The ' $a$ ' and ' $b$ ' indicate $\mathrm{P}<0.05$ differences. 

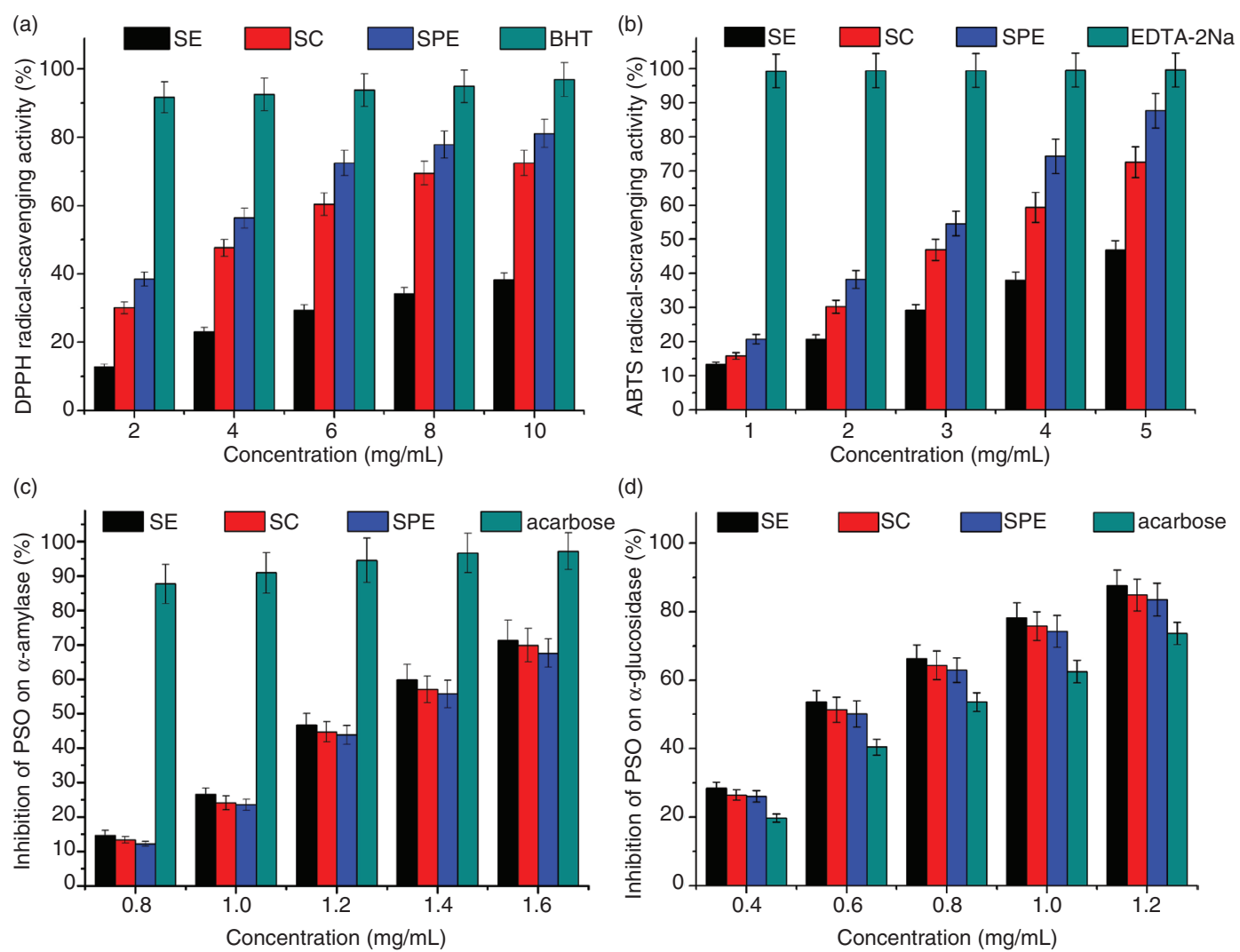

(d)

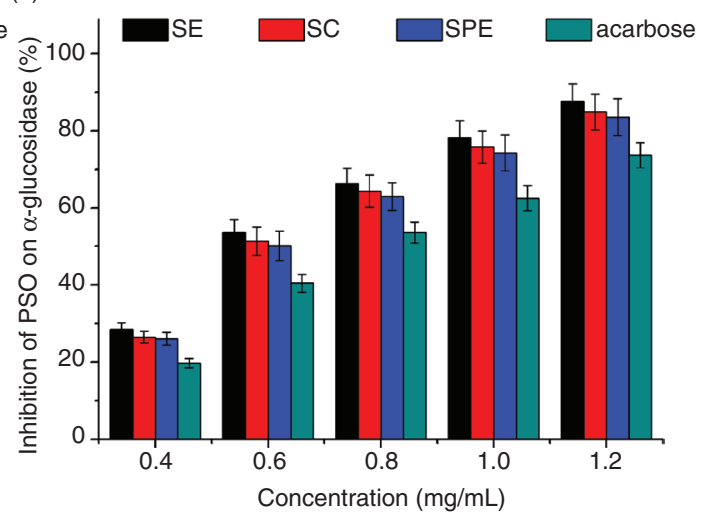

FIGURE 1. The antioxidant activity, inhibition activity on enzymes by different PSOs. (a) DPPH radical-scavenging activity; (b) ABTS $^{+}$radical-scavenging activity; (c) $\alpha$-amylase; (d) $\alpha$-glucosidase. Each value is an average of three determinations, mean \pm SD.

96.89\% at this concentration (Figure 1a). A similar pattern was observed for the $\mathrm{ABTS}^{+}$radical-scavenging activity of all PSOs, $87.69 \%, 72.63 \%$ and $46.79 \%$ for SPE, SC and SE at $5 \mathrm{mg} / \mathrm{mL}$, respectively; the activity of EDTA-2Na (as control) was $99.63 \%$ at this concentration (Figure 1b). The phenomenon of SPE oils displaying higher antioxidant activity than other methods was also reported in other fruit or seed oils, which may be attributed to the new antioxidant components by the Maillard reaction induced by the high temperatures in screw pressing (Nicoli et al., 1999; Dong et al., 2014).

\subsection{Inhibitory effects of PSOs on $\alpha$-amylase and a-glucosidase}

The inhibitory effects of PSOs that reduced the activity of $\alpha$-amylase and $\alpha$-glucosidase are summarized in Figure 1c,d. All PSO samples displayed strong $\alpha$-glucosidase inhibition activity compared with the inhibitory activity against $\alpha$-amylase. The inhibition effect of oils on both $\alpha$-amylase and $\alpha$-glucosidase were found to be concentration dependent. The inhibition effect on $\alpha$-glucosidase ranged from $28.46 \%$ to $87.57 \%$ while the concentration of SE oils increased from $0.4 \mathrm{mg} / \mathrm{mL}$ to $1.2 \mathrm{mg} / \mathrm{mL}$.
The inhibitory potential of SC oils and SPE oils was lower than observed in SE oils, but it was still higher than acarbose. The inhibition effects of SE oils on $\alpha$-amylase were $71.25 \%$ at $1.6 \mathrm{mg} / \mathrm{mL}$ which was higher than SC and SPE oils. Su et al. (2015) reported that the inhibition effect of PSOs on $\alpha$-glucosidase and $\alpha$-amylase reached $50 \%$ at $0.61 \mathrm{mg} / \mathrm{mL}$ and $1.23 \mathrm{mg} / \mathrm{mL}$, respectively. The present studies have shown that oleic acid, linoleic acid and $\alpha$-Linolenic acid could be the major active constituents, which contributed to the potency in inhibiting $\alpha$-glucosidase and $\alpha$-amylase activity, which is in agreement with the previous studies (Kim et al., 2014).

\subsection{Thermal analysis of the PSOs}

The samples showed different thermal behaviors during the cooling and heating phases. The heat released (exotherm) during cooling was found to be less than the heat absorbed (endotherm) during heating (Wang and Briggs, 2002). The crystallization and melting curves of PSOs determined by DSC were shown in Figure 2. The thermal properties of the three types of oils were similar, and displayed a similar melting peak and crystalline peak. Wang $\mathrm{T}$ and Briggs JL reported that the thermal properties of oils 
were mainly influenced by the content of oleic acid and the saturation of oils (Wang and Briggs, 2002). Thus, the thermal results further demonstrated that there was no significant difference in the composition of the three types oils (Table 1). Two exothermic peaks were observed in SPE oils during cooling, but only one peak was denoted to SC and SE oils. The crystalline peaks of the PSOs were relatively more narrow than the melting peaks (Figure 2), which confirmed that the onset and completion temperatures

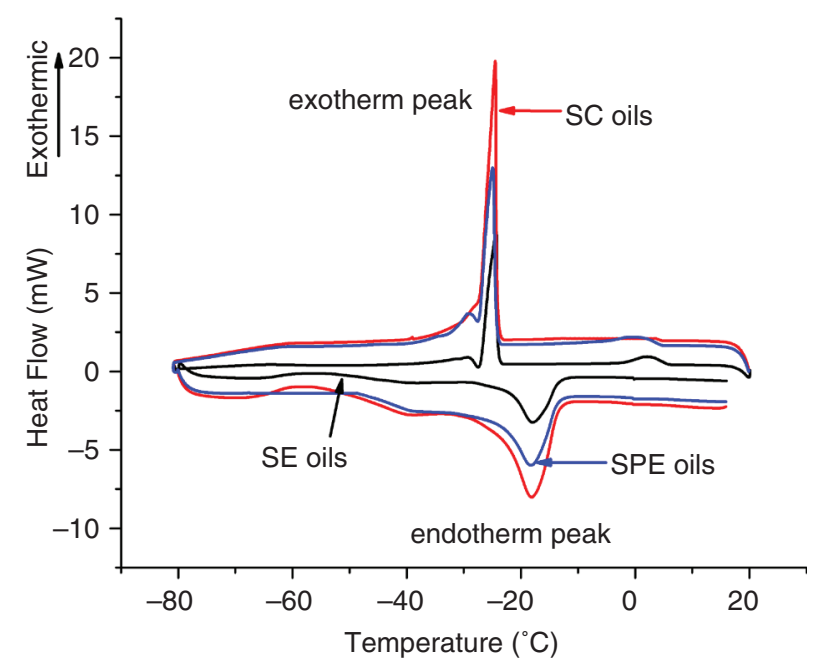

Figure 2. DSC thermal analysis of SE, SC and SPE oils. from the crystallization curves were much better defined than those of the melting curves.

\subsection{Rheological properties analysis}

The viscosities of the three oils samples decreased with the increase in temperature (Figure 3). The viscosity of SE and SPE oils was higher than that of SC oil at sheer rate $>10 \mathrm{~s}^{-1}$ at $10^{\circ} \mathrm{C}$ (Figure 3a). When monitoring at 30 and $50{ }^{\circ} \mathrm{C}$, this difference almost vanished (Figure 3b, c). It was observed that the greater molecular movement and a reduction in the intermolecular bond forces contributed to promoting flux increases and reduced viscosity at high temperatures (Liu et al., 2012). As the shear rate increased, the shear stress was enhanced gradually (Figure 3d-f). A linear relation was observed between the shear stress and shear rate at higher shear rates, when PSOs behaved as a Newtonian fluid. The Casson equation was further used to describe the flow behavior of three oils and summarized in Table 4 . The higher shear limiting viscosity $\left(\eta_{c}\right)$ of SE oils was greater than that of SC and SPE oils at each temperature. In addition, the $\eta_{\mathrm{c}}$ values of three samples decreased with the increased temperature. The influence of temperature on viscosity for PSOs was further expressed in an Arrhenius type of equation (supplemental Figure 1), and the detailed thermodynamic parameters of oils are shown in Table 5. The viscosity of the three oils decreased with an increase in temperature at $100 \mathrm{~s}^{-1}$.
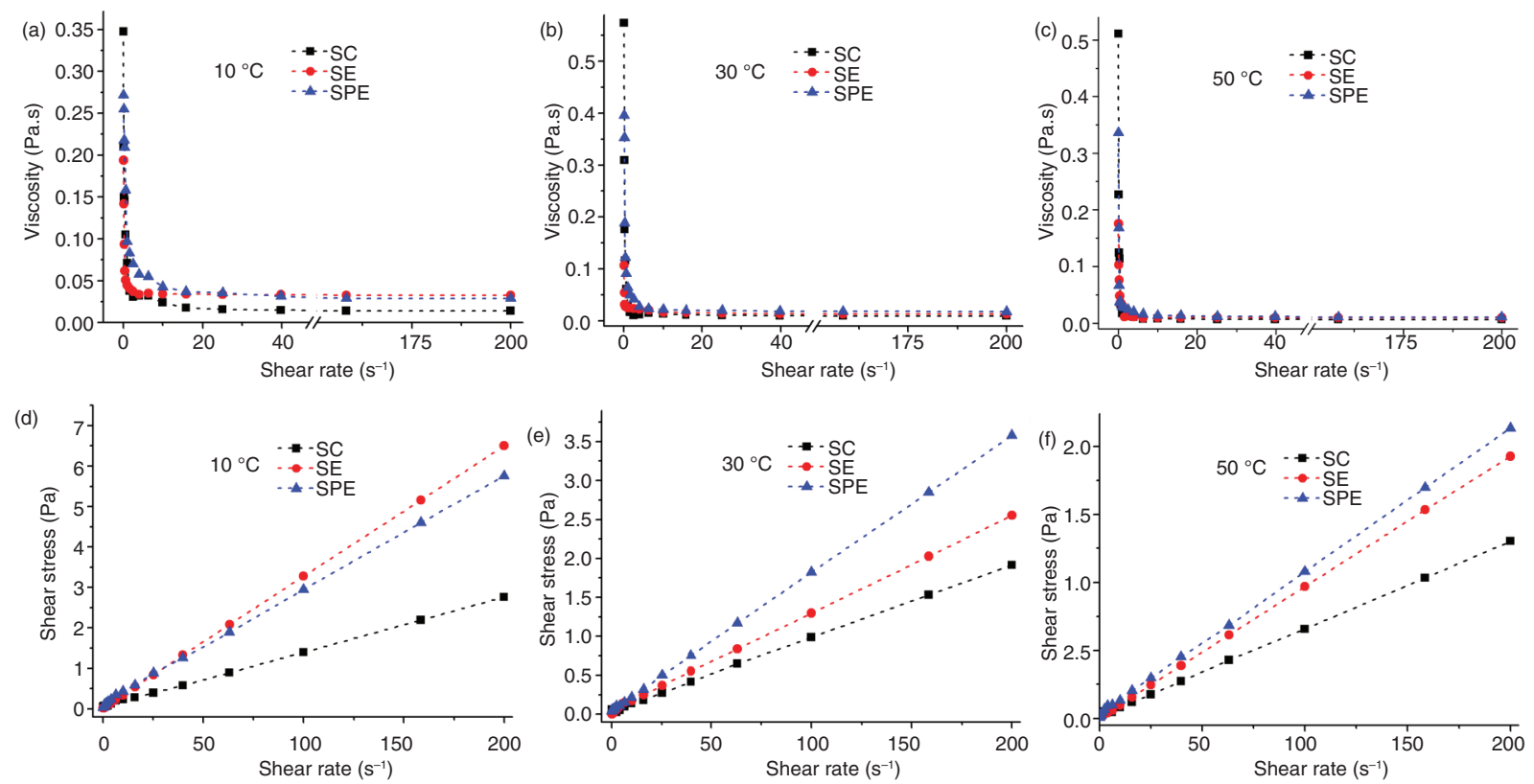

Figure 3. Comparison of viscosity versus shear rate curve of different extraction oils at different temperature. (a), (b) and (c) represent the values at $10{ }^{\circ} \mathrm{C}, 30^{\circ} \mathrm{C}$ and $50{ }^{\circ} \mathrm{C}$, respectively. Viscosity of samples was measured at various shear rates from 0.1 to $200 \mathrm{~s}^{-1}$. The Casson equation was used to describe the flow behavior of the three oils, (d), (e) and (f) represent the values at $10^{\circ} \mathrm{C}$, $30^{\circ} \mathrm{C}$ and $50{ }^{\circ} \mathrm{C}$, respectively. 
TABLE 4. Flow parameters for peony seed oils by the Casson model at various temperatures

\begin{tabular}{|c|c|c|c|c|c|c|}
\hline \multirow[b]{2}{*}{ Oil samples } & \multicolumn{2}{|c|}{$10{ }^{\circ} \mathrm{C}$} & \multicolumn{2}{|c|}{$30^{\circ} \mathrm{C}$} & \multicolumn{2}{|c|}{$50^{\circ} \mathrm{C}$} \\
\hline & $\tau 0$ & $\eta \mathbf{c}$ & $\tau 0$ & $\eta c$ & $\tau 0$ & $\eta c$ \\
\hline SC oils & $1.41 \mathrm{E}-2$ & $1.14 \mathrm{E}-2$ & $8.61 \mathrm{E}-3$ & $8.12 \mathrm{E}-3$ & $4.45 \mathrm{E}-3$ & $5.57 \mathrm{E}-3$ \\
\hline SE oils & $1.48 \mathrm{E}-3$ & $3.13 \mathrm{E}-2$ & $6.32 \mathrm{E}-4$ & $1.66 \mathrm{E}-2$ & $6.71 \mathrm{E}-4$ & 9. $78 \mathrm{E}-3$ \\
\hline SPE oils & $2.29 \mathrm{E}-2$ & $2.48 \mathrm{E}-2$ & $6.43 \mathrm{E}-3$ & $1.61 \mathrm{E}-2$ & $2.96 \mathrm{E}-3$ & 9. $52 \mathrm{E}-3$ \\
\hline
\end{tabular}

Mean $\tau_{0}$ yield stress, $\eta_{\mathrm{c}}$ higher shear limiting viscosity.

TABLE 5. Thermodynamic parameters of oils derived from the Arrhenius type of equation

\begin{tabular}{lcccc}
\hline Oil samples & A (Pa.s) & Ea $(\mathbf{c a l} / \mathbf{m o l})$ & Ea/R & SE \\
\hline SC oils & $3.35 \mathrm{E}-5$ & 3399.18 & 1711.57 & 140.91 \\
SE oils & $1.79 \mathrm{E}-6$ & 5519.91 & 2779.41 & 54.58 \\
SPE oils & $9.19 \mathrm{E}-6$ & 4547.98 & 2290.02 & 142.45 \\
\hline
\end{tabular}

Each value is an average of three determinations, mean $\mathrm{R}$ universal gas constant $=1.986 \mathrm{cal} / \mathrm{mol} \mathrm{K}$. SE standard error.

The results suggest that the differences in viscosity among the oils decrease as temperature increase, which means that the extraction methods have little influence on the viscosity for those oils at a higher temperature. It was found that the values of $E_{a}$ of SC oil was lower than those of SE and SPE oils, which suggested that $\mathrm{SC}$ oil had a gradual change in viscosity with temperature.

\section{CONCLUSION}

Peony seed oil is rich in oleic, linoleic and $\alpha$-linolenic acid. The contents of FAs in oils extracted by SE, SC and SPE methods showed nonsignificant differences, and resulted in a similar melting and crystalline point. The result of the ${ }^{1} \mathrm{H}$ NMR analysis reflected the fact that the content of UFAs in SPE oils was less than observed in SE and SC oils after confirmation with the analysis of GC-MS. The SC and SPE oil samples exhibited a greater radicalscavenging activity than the SE oil sample. Three oil samples have similar enzyme-inhibitory activity, and revealed a strong anti- $\alpha$-glucosidase activity whereas, weaker anti- $\alpha$-amylase activity. The SC oils had lower viscosity compared with the others, although this difference reduced gradually as the temperature rose. The temperature has less impact on the viscosity of oils extracted by SC.

\section{ACKNOWLEDGEMENT}

This study was supported by the Major projects of science and technology in the Anhui Province (15czz03115), the Project of Natural Science Foundation of the Anhui Province (1408085MC57), the Key projects of Natural Science Research of the Anhui Province (KJ2016A575), and the Special Fund for Agro-scientific Research in the Public Interest of China (201403064).

\section{REFERENCES}

Abd Ghafar SA, Ismail M, Saiful YL, Fakurazi S, Ismail N, Chan KW, Md TP. 2013. Cytotoxic activity of kenaf seed oils from supercritical carbon dioxide fluid extraction towards human colorectal cancer (HT29) cell lines. Evid. Based Complement. Alternat. Med. Article ID 549705. http://dx.doi.org/10.1155/2013/549705

Azhari S, Su YS, Jiang QX, Xia WS. 2014. Physicochemical properties and chemical composition of Seinat ( Cucumis melo var. tibish ) seed oil and its antioxidant activity. Grasas Aceites 65, e008. http://dx.doi.org/10.3989/ gya. 074913

Azmir J, Zaidul ISM, Sharif KM, Uddin MS, Jahurul MHA, Jinap S, Hajeb P, Mohamed A. 2014. Supercritical carbon dioxide extraction of highly unsaturated oil from Phaleria macrocarpa seed. Food Res. Int. 65, 394-400. http://dx.doi. org/10.1016/j.foodres.2014.06.049

Chen F, Zhang X, Zhang Q, Du X, Yang L, Zu Y, Yang F. 2016. Simultaneous synergistic microwave-ultrasonic extraction and hydrolysis for preparation of trans -resveratrol in tree peony seed oil-extracted residues using imidazolium-based ionic liquid. Ind. Crops Prod. 94, 266-280. http://dx.doi. org/10.1016/j.indcrop.2016.08.048

Diaby M, Amza T, Onivogui G, Zou XQ, Jin QZ. 2016. Physicochemical and antioxidant characteristics of gingerbread plum (Neocarya macrophylla) kernel oils. Grasas Aceites 67, e117. http://dx.doi.org/10.3989/gya.0362151

Dong Z, Zhang JG, Tian KW, Pan WJ, Wei ZJ. 2014. The fatty oil from okra seed: supercritical carbon dioxide extraction, composition and antioxidant activity. Curr. Top. Nutraceut. R. 12, 75-84.

Han CV, Bhat R. 2014. In vitro control of food-borne pathogenic bacteria by essential oils and solvent extracts of underutilized flower buds of Paeonia suffruticosa (Andr.). Ind. Crops Prod. 54, 203-208. http://dx.doi.org/10.1016/j. indcrop.2014.01.014

Jadhav SB, Singhal RS. 2013. Screening of polysaccharides for preparation of alpha-amylase conjugate to enhance stability and storage life. Carbohydr. Polym. 92, 1724-1729. http://dx.doi.org/10.1016/j.carbpol.2012.11.009

Kim KT, Rioux LE, Turgeon SL. 2014. Alpha-amylase and alpha-glucosidase inhibition is differentially modulated by fucoidan obtained from Fucus vesiculosus and Ascophyllum nodosum. Phytochemistry 98, 27. http:// dx.doi.org/10.1016/j.phytochem.2013.12.003

Li SS, Yuan RY, Chen LG, Wang LS, Hao XH, Wang LJ, Zheng XC, Du H. 2015. Systematic qualitative and quantitative assessment of fatty acids in the seeds of 60 tree peony 
(Paeonia section Moutan DC.) cultivars by GC-MS. Food Chem. 173, 133-140. http://dx.doi.org/10.1016/j. foodchem.2014.10.017

Liu C, Mei Y, Huang F. 2012. Influence of extraction processing on rheological properties of papeseed oils. $J$. Am Oil Chem. Soc. 89, 73-78. http://dx.doi.org/10.1007/ s11746-011-1892-y

Luzzi AF, James WPT. 2001. European diet and public health: The continuing challenge. Public Health Nutr. 4, 275-292. http://dx.doi.org/10.1017/S1368980001001549

Nicoli MC, Anese M, Parpinel M. 1999. Influence of processing on the antioxidant properties of fruit and vegetables. Trends Food Sci. Tech. 10, 94-100. http://dx.doi. org/10.1016/S0924-2244(99)00023-0

Ning C, Jiang Y, Meng J, Zhou C, Tao J. 2015. Herbaceous peony seed oil: A rich source of unsaturated fatty acids and $\gamma$-tocopherol. Eur. J. Lipid Sci. Tech. 117, 532-542. http:// dx.doi.org/10.1002/ejlt.201400212

Pang M, He SJ, Cao LL, Jiang ST. 2015. Optimization and evaluation of foxtail millet (Setaria italica) bran oil by supercritical carbon dioxide extraction. Grasas Aceites 66, e107. http://dx.doi.org/10.3989/gya.0239151

Pederssetti MM, Palú F, Da SE, Rohling JH, Cardozofilho L, Dariva C. 2011. Extraction of canola seed (Brassica napus) oil using compressed propane and supercritical carbon dioxide. J. Food Eng. 102, 189-196. http://dx.doi. org/10.1016/j.jfoodeng.2010.08.018

Pradhan RC, Meda V, Rout PK, Naik S, Dalai AK. 2010. Supercritical $\mathrm{CO}_{2}$ extraction of fatty oil from flaxseed and comparison with screw press expression and solvent extraction processes. J. Food Eng. 98, 393-397. http:// dx.doi.org/10.1016/j.jfoodeng.2009.11.021

Sathivel S, Prinyawiwatkul W, Negulescu II, King JM, Basnayake BFA. 2003. Effects of purification process on rheological properties of catfish oil. J. Am. Oil Chem. Soc. 80, 829-832. http://dx.doi.org/10.1007/s11746-003-0780-3

Sevim D, Senol FS, Gulpinar AR, Orhan IE, Kaya E, Kartal M, Sener B. 2013. Discovery of potent in vitro neuroprotective effect of the seed extracts from seven Paeonia L. (peony) taxa and their fatty acid composition. Ind.
Crops Prod. 49, 240-246. http://dx.doi.org/10.1016/j. indcrop.2013.05.001

Shi JJ, Zhang JG, Sun YH, Qu J, Li L, Prasad C, Wei ZJ. 2016. Physicochemical properties and antioxidant activities of polysaccharides sequentially extracted from peony seed dreg. Int. J. Biol. Macromol. 91, 23-30. http://dx.doi. org/10.1016/j.ijbiomac.2016.05.082

Su J, Wang H, Ma C, Lou Z, Liu C, Tanver Rahman M, Gao C, Nie R. 2015. Anti-diabetic activity of peony seed oil, a new resource food in STZ-induced diabetic mice. Food Funct. 6, 2930-2938. http://dx.doi.org/10.1039/C5FO00507H

Wang C, Xu L, Wu O, Zhou Z, Ren X, Yang R. 2015. The importance of ultrahigh pressure processing over the quality of the extracted oil from peony seeds ( Paeonia suffruticosa Andr.). Ind. Crops Prod. 76, 1142-1147. http://dx.doi. org/10.1016/j.indcrop.2015.08.021

Wang LS, Hashimoto F, Shiraishi A, Aoki N, Li JJ, Sakata Y. 2004. Chemical taxonomy of the Xibei tree peony from China by floral pigmentation. J. Plant Res. 117, 47-55. http://dx.doi.org/10.1007/s10265-003-0130-6

Wang T, Briggs JL. 2002. Rheological and thermal properties of soybean oils with modified FA compositions. J. Am. Oil Chem. Soc. 79, 831-836. http://dx.doi.org/10.1007/ s11746-002-0566-7

Wei ZJ, Liao AM, Zhang HX, Liu J, Jiang ST. 2009. Optimization of supercritical carbon dioxide extraction of silkworm pupal oil applying the response surface methodology. Bioresour. Technol. 100, 4214 4219. http://dx.doi. org/10.1016/j.biortech.2009.04.010

Zhang J, Liu Y, Lv J, Li G. 2015. A colorimetric method for $\alpha$-glucosidase activity assay and its inhibitor screening based on aggregation of gold nanoparticles induced by specific recognition between phenylenediboronic acid and 4-aminophenyl- $\alpha$-D- glucopyranoside. Nano Res. 8, 920-930. http://dx.doi.org/10.1007/s12274-014-0573-1

Zhu TH, Cao SW, Yu YY. 2013. Synthesis, characterization and biological evaluation of paeonol thiosemicarbazone analogues as mushroom tyrosinase inhibitors. Int. J. Biol. Macromol. 62, 589. http://dx.doi.org/10.1016/j. ijbiomac.2013.09.056 
10 J. Qu, F. Zhang, K. Thakur, J.J. Shi, J.G. Zhang, S. Faisal and Z.J. Wei

\section{Supplementary data}

Supplementary Table 1. Predicated value and observed value for the oil yield

\begin{tabular}{lcc}
\hline Variables & $\begin{array}{c}\text { Predicated } \\
\text { conditions }\end{array}$ & $\begin{array}{c}\text { Modified } \\
\text { conditions }\end{array}$ \\
\hline Presser $(\mathrm{MPa})$ & 23.958 & 240 \\
$\mathrm{CO}_{2}$ flow rate $(\mathrm{L} / \mathrm{h})$ & 20.601 & 21 \\
Extraction temperature $\left({ }^{\circ} \mathrm{C}\right)$ & 45.622 & 46 \\
Extraction time $(\mathrm{min})$ & 124.158 & 124 \\
Oil yield $(\%)$ & 27.12 & 27.83 \\
\hline
\end{tabular}

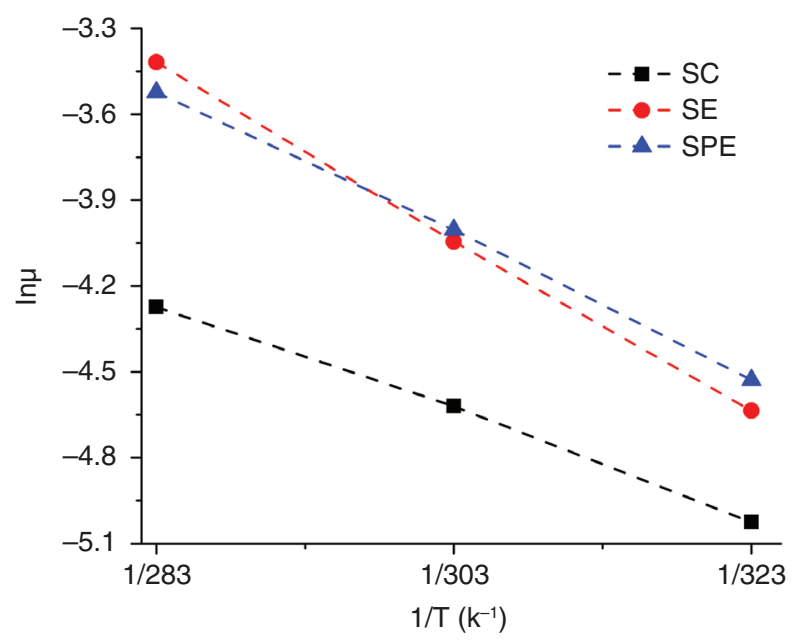

Supplementary Figure 1. Effect of temperature on viscosity of different PSOs. The influence of temperature on viscosity of oils was expressed in an Arrhenius type of equation. 